Historic, Archive Document

Do not assume content reflects current scientific knowledge, policies, or practices. 

The prices in this catalogue are for the \&oods packed and delivered to transportini azent in Lexington. Heavy shipments may be sent by frelght; but we strondly advise the forwardin\& of zoods by express' whenever practicable. Small packa\&es may be sent by Parcel Post at purchaser's expense.

Deliveries by Motor Truck are made to all points within reasonable distance of our nursery. The chardes for such service are based upon distance and weight, and are usually less than express charges for similar shipments. This method eliminates the close packind otherwise necessary, and also insures prompt arrival of coods at destination with minimum exposure.

Unless method of shipment is specified, we use our discretion.

BRECK-ROBINSON NURSERY COMPANY

Munroe Station, Lexington TELEPHONE LEXINGTON 260 


\section{Visit Our Nurseries}

Trains from North Station, Boston.

Electric Cars by way of Harvard

Square, Cambridge, and Arlington

Heights. Trains and Cars stop at

Manroe Station, which is at our

entrance. Good motoring roads

from all directions. Ten miles

from Boston.

BRECK-ROBINSON NURSERY CO.

Munroe Station, Lexington, Mass. 



\section{ROSES \\ OUT - \\ - of - DOORS For DECORATIVE and GUT FLOWER PURPOSES}

$\mathbf{N}$ O other flower holds quite so warm a place in the human heart as the rose. It is among the oldest of cultivated plants, and from the earliest times has been the synonym for perfection. It has figured in the literature of all ages and of all nations, being honored alike by poet and king. It is the one flower known to all people, and is loved alike by poor and rich. It may be growing in the door-yard of the unpretentious cottage or on the grounds of the large estate; wherever found it is recognized as the "Queen of flowers."

In this first edition of "Roses Out-of-Doors" it is our purpose to give such information concerning the culture and uses of this old garden favorite, as will enable all flower-lovers who are willing to give attention to a few pleasant details to have a "feast of flowers" from June to frost.

\section{ROSES FOR EVERY PURPOSE}

While botanically there are more than a hundred distinct forms of Rosa only a dozen or so are well-known in horticulture; but these afford material for purposes which may in general be classified as follows:

FOR NATURAL EFFECTS AND MASS PLANTING
For the border, lawn, and landscape, where foliage as well as floral effect is to be secured by mass-planting, aative species and those least modified by man's crossing and selection are most suitable. This type is perhaps best represented by R. rugosa,

R. setigera, R. multiflora, etc. Being hardy, of moderately fres growth, with foliage resistant to the attack of insects and disease, these shrubby sorts not only create pleasing natural effects, but when once established require little care to preserve their beauty. Very good illustrations of the uses of these natural forms may be found in the plantings along the parkways and boulevards of Greater Boston. These same natural effects, modified to suit conditions, may be appropriately reproduced in groupings along the drives, in the borders or about the bases of buildings of the home-grounds.

\section{FOR ROCK, WALL AND} GROUND COVERS
Another form of natural beauty may be secured by the use of what may he termed cover-roses or trailers. With these, banks, stumps, walls, fences and other bare or unsightly objects may be partly or entirely covered, as may be desired. The Wichuraianas are the most popular of the cover-roses; they are remarkably free from both insects and disease, with foliage clean, bright and shiny, almost evergreen. During the blooming period, in mid-summer, they hear a great profusion of flowers, singly or in clusters, the single-flowered ones being followed by bright red berries which the birds like.

\section{FOR COVERING SCREENS TRELLISES AND PERGOLAS}

Very often in the rear of the house or lawn may be found some unsightly object, the screening of which would add greatly to the attractiveness of the grounds. Climbing roses, supported on a simple trellis or fence of the proper height, will accomplish this purpose, and at the same time add a pleasing feature. Various designs and materials are available for the construction of trellises and other supports; but a simple structure of wood, painted green or white, is usually the most satisfactory,

Besides the foregoing, there remain numberless opportunities to use roses in the covering of arches, arbors, summerhouses, porches, etc.

New and improved forms in Climbing and Pillar roses allow a wide range of choice in the selection of varieties. The best-known are of the "multiflora" type, of which the Crimson Rambler is a popular example; but some of the later productions, the large-flowered Climbing Hybrid Teas, for instance, are remarkably beautiful.

\section{GARDEN ROSES, CHIEFLY FOR CUTTING} and perfection of the blooms which they yield.

Of all flowers which are intended primarily for cutting, roses should be given an important place in the home grounds. They require more thorough cultivation than some garden flowers; but any additional attention is more than repaid in the beauty

The roses snitable for cut-flower purposes are grouped urder heads which, in general, indicate their origin. They differ somewhat in hardiness and cultural requirements, as well as in characteristics of growth and bloom. Good judgment should be used in selecting varieties suited to the climate in which they are to be planted, and to the sitnation and care which is to be given them. The principal groups which include most of the hybrids adapted to garden culture, are as follows: 
HYBRID PERPETUALS. These, the hardiest of the cut-flower roses, are the only ones which can be relied upon to flourish in the colder parts of the country without protection in winter. They are upright, stiff, and woody in growth, blooming freely in the early summer, and frequently a second time if thoroughly pruned, especially if checked in mid-summer by dry weather. The flowers are large and full.

HYBRID TEAS. A most desirable and valuable class of roses for out-of-door planting, which, when properly treated, give an abundance of flowers from spring until cold weather. They are a comparatively new race of garden roses, ereated by crossing Hybrid Perpetuals with the less hardy Tea roses; while they already cover a wide range of color, new and excellent varieties are being developed annually. Their popularity is steadily increasing as their excellent blooming qualities become known. We are not so sanguine as some American growers as to the absolute hardiness of the Hybrid Teas; but with winter protection they are reasonably sure to withstand even our northern New England climate.

TEA ROSES, with the Bengals, Bourbons, and Chinas, all produce beautiful flowers for cutting, and are excellent bedding roses. They are not so hardy out-of-doors as the Hybrid Perpetuals and Hybrid Teas; but they are a delight to the eye of every rose-lover, while their fragrance is bcyond comparison with that of any other of Nature's garden gifts. Considered as bedding plants, an investment of a few dollars in these "tender" varieties will give higger returns in flowers during the summer months than can be had from any other class of plants, even though they be allowed to perish with winter.

STANDARD OR TREE ROSES are a most desirable acquisition to the rose garden, being obtainablc in many good varieties. They should, however, have special eare and treatment to be a success. If planted in large pots or tubs, plunged in the ground so that the top of the pot is two inches bolow the surface of the soil, they ean be easily lifted and moved into the cold-cellar in the late fall, or laid down and covered with earth and litter to prevent them from excessive freezing.

\section{POSITION AND SOIL}

The first and most important requisite in the culture of roses is the seleetion and thorongh preparation of a suitable place for planting. In our climate, roses grown for perfection of hloom are not as a rulc decorative plant:, while they require more room and better cultivation than plants adapted to horder massing. It is therefore well to give them a bed by themselves, and perhaps to locate it in a secluded part of the grounds or garden.

A sunny, protected position is most essential, and if so situated that there is exposure to the morning sum, with partial shade in the afternoon, all the better; hut a eertain amount of sunlight is necessary and roses show their appreciation of it more freely than almost any other flower. An ideal spot is on the sunny side of a hedge, a hoard fence, or a close-growing group of trees. When a fenee is the protecting medium, its gencral ugliness can appropriately be clothed by climbing roses. A hedge or line of shrubs can easily he planted, if a protected spot is not already availahlc.

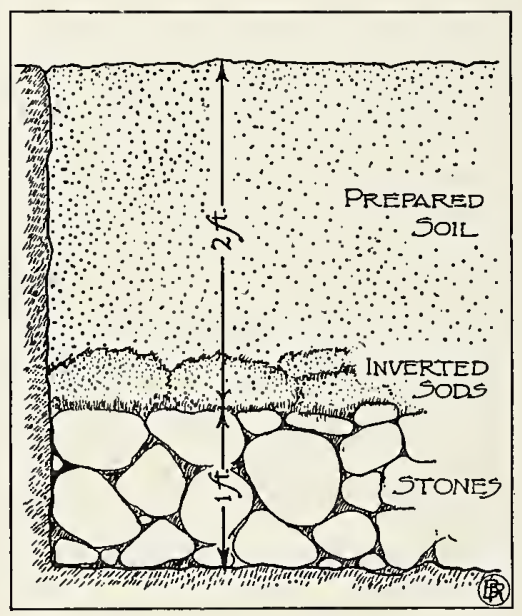

Fig. 1. Structure of Ideal Rose-Bed

Avoid planting under the shadow of overhanging buildings or in close proximity to large trees, for under either condition a rose can never be expected to thrive. Robbed of sunlight from above, or robbed of soil and moisture by roots below, it soon sickens, droops and dies. Whether planted in the garden or arranged singly or in groups in the border, let your roses have the sunlight, pure air and protection from bleak winds. In laying out the bed, it should be so arranged as to be easily accessihle for cultivation and for gathering of blooms. Four fect is generally accepted as the most practical width.

In eonnection with the choice of location, see that the roses are provided with proper soil. They do well in any good garden soil that is free from standing water; thorough drainage and a plentiful supply of organie matter, with a reasonably constant water supply during the growing season, are essential. The deepcr the soil and the better the preparation at the beginning, the more satisfactory will he the results. Being great "feeders," requiring rich food, it is difficult to make the soil for roses too rich. The Hybrid Perpetuals, as well as the heavier-growing climbers, like a heavy elay loam; the Teas, Hyhrid Teas, and the like, revel in a lighter, warmer soil, composed of less clay or heavy loam and more sand or leaf-mold. In either case, use plenty of well-rotted manure in preparing the beds.

\section{BRECK-ROBINSON NURSERY GOMPANY}


The best prepared rose bed is one that has been excavated to a depth of not less than two feet and refilled with a mixture of turf, good loam and well-rotted cow manure in equal parts. A sprinkling of coarse bone-meal in addition is excellent. If the bed should be located where the drainage is poor, the excavation should be made a foot deeper and this filled in with rubble or small stones. On top of the stones, place the inverted turf, and follow with the loam and manure well mixed. (See fig. 1.)

\section{PLANTING}

THE TIME for planting roses varies with the kind of plants used, the location, and somewhat on the season. Dormant plants of only the hardier sorts should be planted in the fall or early spring. If planted in the fall they should be mulched well with coarse manure or leaves, and should not he pruned back until spring. When planted in the spring, they should be set not later than Mlay first. Only good Amelican, English or lrisli-grown stock should he used. The soft, heavy-wooded, Holland-grown stock often fails to survive, even with the best of care in planting. Pot-grown roses can be planted at any time during the season from May to October. The ideal time, however, is during the inonth of May, when the plants will be received full of buds and ready to commence blooming.

THE BEST ROSES to plant are two-year-olds that have been potted in advance in roomy pots, and have thus become equipped with a fibrous, active root-system, guaranteeing results from the start. In the use of these plants, all risk such as generally attends the planting operation has been eliminated. Our pot-grown Roses are winter potted, and will be ready for May or later shipments. Dormant plants of all the leading varieties can be furnished for autumn or early spring planting; these are good, strong two-year-old, field-g rown plants, budded on the best briar stock, but on these dormant plants we assume no risk after setting out. We shall discontinue filling orders for dormant plants on May first.

THE DISTANCE AND DEPTH for planting, depend upon the sind, vigor of growth, and purpose of the roses used. Hybrid Perpetuals, and the more vigorous Hybrid Tcas, should be set from two to three feet apart. When a great mass of bloom is wanted, the vigorous sorts had better be three feet apart; but for cut-flowers, when they are pruned to produce individual blossoms, twenty-four to thirty inches is probably far enough. Teas and other lighter-growing varieties, intended for bedding and cut-flowers, can be set from eighteen to twenty-four inches apart.

When planting pot-grown roses, the ball of earth surrounding the roots should be placed two and one-half inches below the surface level of the bed, the soil filled in to the top of the ball and carefully firmed; then apply water, and when thoroughly saturated, fill in the remaining soil, firm and level, even with the surface of the bed. Dormant roses should he set so that the point of union between the "bud" and the "stock" is about two inches below the surface of the bed. (See fig. 2.) Make the soil very firm around the roots, and water well after planting.

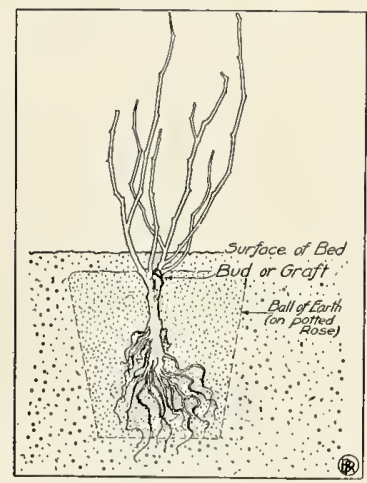

Flg. 2. Depth for planting

\section{CULTURE AND CARE}

The rose-bed should be cultivated every week or ten days until mid-summer, and occasionally from then until frost. The purpose of this is not only to prevent the growth of weeds, but to conserve the moisture about the roots of the plants. Plenty of water should be applied during dry periods; a light syringing during the latter part of the day will also be found beneficial. In dry weather it is well to occasionally draw the surface soil away from the plant, forming a basin that will contain about a gallon of water. Fill this several times, or until the water is not readily absorbed, and cultivate as soon afterwards as the soil can be freely worked.

INSECTS sometimes attack the roses. The most persistent pest is the green fly or aphis, which appears on the young growth early in the season. To destroy it a "contact" spray is necessary, which kills hy caustic action on the outside of its body. Nico-Fume Liquid and soft soap will be found an infallible remedy. Dissolve a heaping tablespoonful of soap in three gallons of water, to which add one tablespoouful of Nico-Fume; mix thoroughly and spray liberally. "Imperial" soap spray is also excellent, using one pint in five gallons of water. Insects which eat the leaves, such as caterpillars, worms and slugs, require a poisonous spray. Hellebore, a heaping tablespoonful to two gallons of water, applied with a syringe or spray pump, will prove fairly effective. Arsenate of Lead and Pyrox are also good poisons, but discolor the foliage. Picking off the worms in the early morning is the most expeditious method of extermination.

MILDEW occasionally appears on the leaves and stems, especially in cold, damp weather. Spray at once with a solution of one ounce of sulphide potassium and eight ounces of sof t soap, dissolved in three gallons of water. Two or three applications insure inmunity. Dusting with powdered sulphur is also effective. 
WINTER PROTECTION. Cut-flower Roses, excepting perhaps the Hybrid Perpetuals, need winter protection in latitudes north of Philadelphia. This may be provided by a heavy mulching of coarse manure, straw or leaves. Evergreen boughs are often helpful in holding the other material in place, besides being a protection in themselves. Individual plants may be wrapped in straw or straw and burlap. There is some danger of trouble from mice when straw or strawy manure is used, especially during hard winters; this is minimized by banking earth about the plants before covering. This hanking of earth to a height of a foot or more may be recommended as a most effective prevention of injury from cold, especially if covered well with manure after the ground first freezes. The earth cover must be promptly removed in early spring, as soon as danger from freezing is past. Climbing roses are usually suffieiently hardy to stand a normal winter; but when planted in exposed locations it is safer to bend the tops down to the ground and cover them with soil and litter. Before covering, the tops may be cut back somewhat, so that the material may be more easily applied. Of course, this should be followed in the spring by the regular pruning. Standard or Tree Roses should be brought into the coldcellar, or laid down and buried in earth and litter before cold weather sets in.

\section{PRUNING}

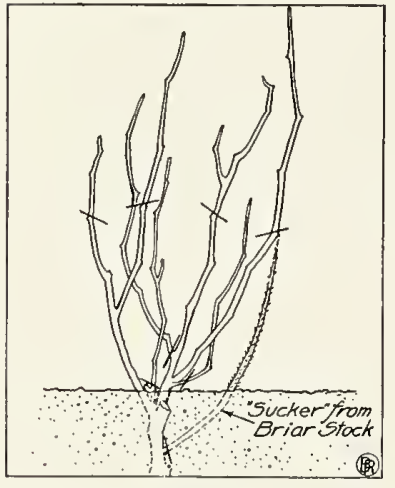

Fig. 3.

Roses grown for cut-fiowers should be severely pruned. The result will be not only better flowers, but prolonged life to the plant. Hybrid Perpetuals and Hybrid Teas should be pruned as early in the spring as weather will permit. Thin out the weak shoots and side growth and cut back the main wood to from four to eight "eyes," leaving about onethird of the previous year's growth. (See fig. 3.) Weak-growing varieties can be eut nearly to the ground and they will produce excellent flowers in June. Dwarf or Bedding roses require only the dead and weaker branches to be removed, pruning the tips back lightly. Climbing Roses should not be pruned severely. Cut out the coarse, heavy wood over two years old; the remaining wood should not be pruned back until after flowering, as the blooms come on last year's growth.

During the growing season, watch the hybrid roses, which are usually budded or grafted on wild or briar stock, for strong-growing shoots, spiny and seven-leaved, that spring from the side of the plant below the ground. This is a "sueker" from the briar stock, and must be removed to prevent its sapping vitality from the blooming wood. Cut it off below ground, close to the root.

Prune at crossmarks after planting

\section{CLASSIFIED LIST OF ROSES}

AUSTRIAN BRIAR

Arhur R. Goodwin

Juliet

Soleil d'Or

CLIMBING TEA

Gloire De Dijon

Nlarechal Niel

\section{CLIMIBING HYBRID TEA}

Climbing Etoile de France

Climbing Gruss an Teplitz

Climbing Helene Gambier

Climbing Helen Gould

Climbing Killarney

Climbing Liberty

Climbing Madame Caroline Testout

Climbing Richmond

Climbing Souvenir of Wootton

Gainsborough or Climbing Viscountess Folkestone

Mrs. Robert Peary or Climbing Kaiserin

\section{CLIMBING POLYANTHA}

Crimson Rambler

Miss G. Mlessmann or Climbing Baby Rambler

Philadelphia Crimson Rambler

Pinls Rambler or Euphrosyne
Tausendschon or Thousand Beauties

Trier

Veilchenblau or Blue Rambler

White Rambler or Thalia

Yellow Rambler or Aglaia

\section{HARDY CLIMBERS}

American Pillar

Baltimore Belle

Christine Wright

Climbing American Beauty

Flower of Fairfield or Everblooming Crimson Rambler

Prairie Queen

\section{HYBRID PERPETUAL}

Alfred Colomb

American Beauty

Anne de Dieshach or Glory of Paris

Baron de Bonstetten

Baroness Rothschild

Captain Hayward

Clio

Earl of Dufferin

Fisher Holmes

Frau Karl Druschki

General Jacqueminot

George Arends or Red Drusehki

George Dickson

Gloire Lyonnaise
His Majesty

Hugh Diekson

John Hopper

La Reine

Madame Gabriel Luizet

Madame Plantier

Magna Charta

Margaret Dickson

Marshall P. Wilder

Mrs. John Laing

Mrs. R. G. Sharman-Crawford

Paul Neyron

Prince Camille de Rohan

Ulrich Brunner

\section{HYBRID RUGOSA}

Alice Aldrich

Blanc de Coubert

Conrad Ferdinand Meyer

Madane George Bruant

Roseraie de L'Hay

\section{HYBRID SWEETBRIAR}

Amy Robsart

Anne of Geierstein

Flora Mclvor

Lady Penzance

Lord Penzance

Lucy Bertram

Meg Merrilies 


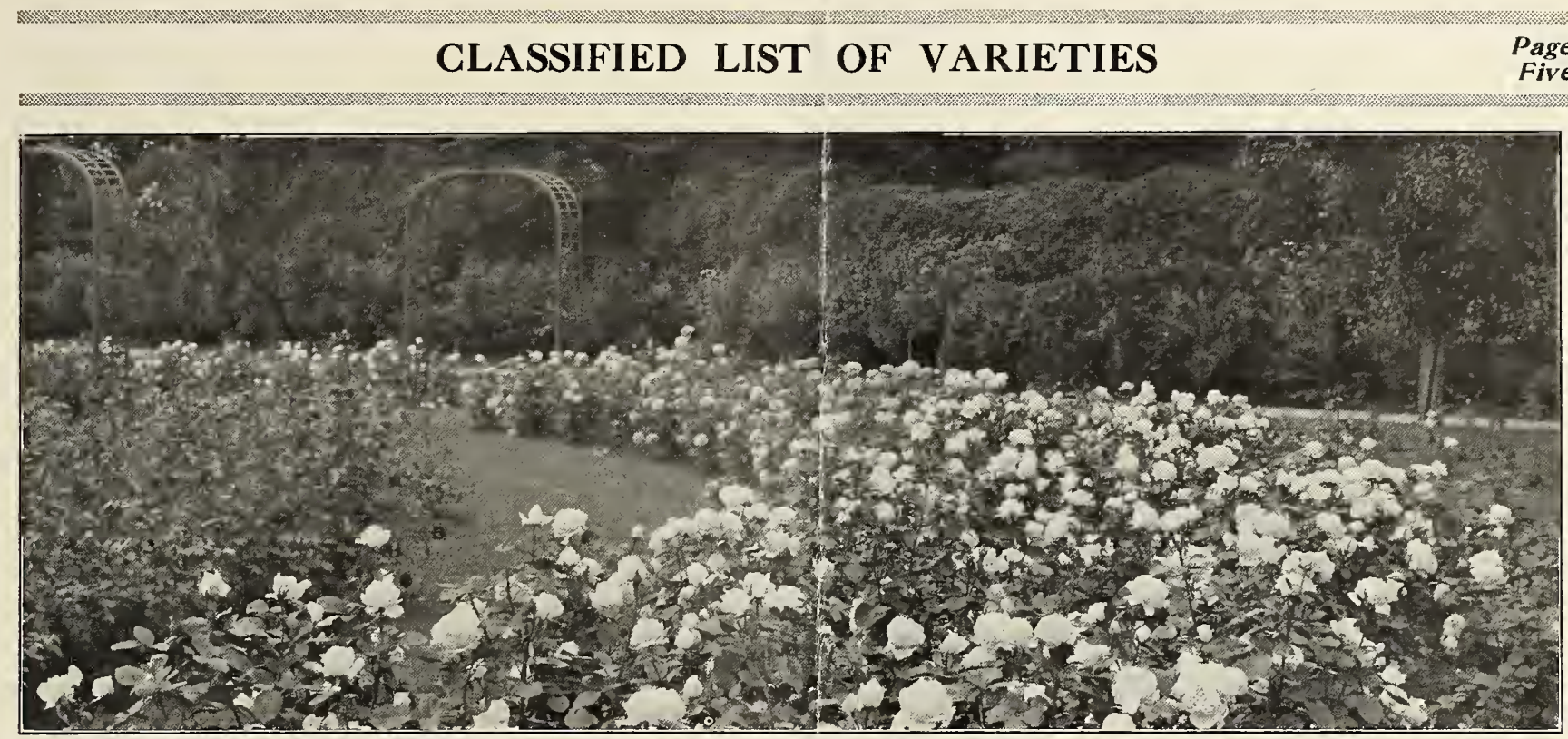

\section{HYBRID TEA}

Antoine Rivoire

Bardo Job

Bessie Brown

Betty

British Queen

Clara Watson

Colleen

Countess of Gossford

Countess of Shaftsbury

Crimson Queen

Dean Hole

Dorothy Page Roberts

Duchess of Albany or Red La France

Duchess of Wellington

Ecarlate

Edith Part

Edward Mawley

Etoile de France or Star of France

Francis Scott liey

Francesca Kruger

General MacArthur

Gencral-Superior Arnold Janssen

George C. Waud

Gruss an Teplitz or Virginia R. Coxe

Hadley

Harry Kirk

Helen Gould

Helene Gambier

Herzogin Marie Antoinette

Hoosier Beauty

Irish Elegance

J. B. Clarke

Jonkheer J. L. Mock

Johannes Wyesselhoft

Joseph Hill

Kaiserin Augusta Victoria

Killarney or The Irish Beauty

Killarney Brilliant

La Detroit

Lady Alice Stanley

Lady Battersea or Red Niphetos

La France

La Progrosse

Laurent Carle

Madame Abel Chatenay

Madame Caroline Testout

Madame Edouard Herriot or Daily Mail Rose
An Unusually Fine Massing of Frau Karl Druschki

Madame Jenny Guillemot

Madame Jules Grolez

Madame Leon Pain

Madame M. Bramberson

Madame Pernet Ducher

Madame Ravary

Iadame Segond Weber

Melody

Meteor

Milady

Mrs. Aaron Ward

Mrs. Arthur Robert Waddell

Irs. George Shawyer

Mistress T. Hillas

My Maryland

Old Gold

Ophelia

Olivia

Perle Von Godesberg or Yellow liaiserin

President Taft

Prince de Bulgarie

Prince d'Arenberg

Queen of Spain

Radiance

Rhca Reid

Richmond

Robin Hood

Souvenir du President Carnot

Sunburst

Tom Wood

Viscountess Folkstine

Wellesley

White Caroline Testout

Whitc Killarney

William Notting

Willowmere

Winnie Davis

\section{HYBRID WICHURAIANA (CLIMBERS)}

Aviateur Bleriot

Debutante

Doctor W. Van Fleet

Dorothy Perkins

Evangeline

Excelsa or Red Dorothy Perkins

Evergreen Gem

Gardenia
Hiawatha

Lady Gay

Manda's Triumph

Prof. C. S. Sargent

Shower of Gold

Silver Moon

South Orange Perfection

Snowdrif

Universal Favorite

White Dorothy Perkins

\section{Moss}

Crested Moss

Princesse Adelaide

Saleì

POLYANTHA (BABY RAMBLERS)

Anny Mueller

Catherine Zeimet or White Baby Rambler

Clothilde Soupert

Erna Teschendorff

Jessie

Louise Welter or Baby Tausendschon Madame Norbert Lavavasseur or Baby Rambler

Maman Lavavasseur, Baby Dorothy or Pink Baby Rambler

Irs. William H. Cutbush

Orleans

Perle d'Or or Yellow Mlle. Cecile Brunner

Mosella or Yellow Soupert

TEA

Alexander Hill Gray

Duchesse de Brabant

Lady Hillingdon

Maman Cochet

Miss Alice de Rothschild

Papa Gontier

Paula

Perle des Jardins

Safrano

Sourenir de Pierre Notting

White Maman Cochet

William R. Smith or Charles Dingee 


\section{VARIETIES OF SPECIAL MERIT}

ARTHUR R. GOODWIN. (A, B.) Onc of Pernet Ducher's great roses. Color in the bud and after the flower opens is very attractive coppery orange-red, shading to salmonpink as the flower ages. The perfectly double blooms are extra large. This has proved a valuable garden rose, being a perpetual bloomer.

$$
2 \text { yr., 50c; X-size, 75c each. }
$$

BRITISH QUEEN. (H. T.) Purest white on opening, but slightly flushed in the bud. Type of flower between White Maman Cochet and Frau Karl Druschki, with Tea Rose form; stiff slender stems; free and fragrant. An allaround rose, valuable alike for exhibiting, massing, bedding and forcing. Gold medal National lose Society.

$$
2 \text { yr., 50c; X-size, 75c. }
$$

EDWARD MAWLEY. (H. T.) A true perpetual-flowering Hybrid Tea and one of the most beautiful of all Roses yct produced. This rose was raised by McGrcdy of treland and named in honor of Edward Nawley, the eminent British rosarian. The color is a rich crimson shaded with velvety maroon. The flowers are of good substance and are freely produced. It received the much coveted gold medal of the National Rose Society of England.

2 yr., 50c; X-size, $75 \mathrm{c}$ each.

FRANCIS SCOTT KEY. (H. T.) This beautiful rose was awarded a silver medal by The American Rose Society of Hartford, Conn., in 1914, and has since been much sought after by discriminating buyers. Abundant in bloom, with rich crimson-red flowers of fine form. It is a heavy double rose of great substance.

$$
2 \text { yr., 50c; X-size, 75c. }
$$

GEORGE ARENDS (Pink Frau Karł Drusehki), ( $H, P$ ) Tlis is a hybrid perpetual rose which, it is predicted, will have the same following as the now famous "White Druschki" within a very few years. Of it a famous rosegrower says: "We have looked it over in the field and have grown it in pots for the market, and we absolutely cannot detect a single fault in or about it." The delicate pink color is unapproachable; flowers singly on the point of each shoot.

$$
2 \text { yr., 50c; X-size, 75c each. }
$$

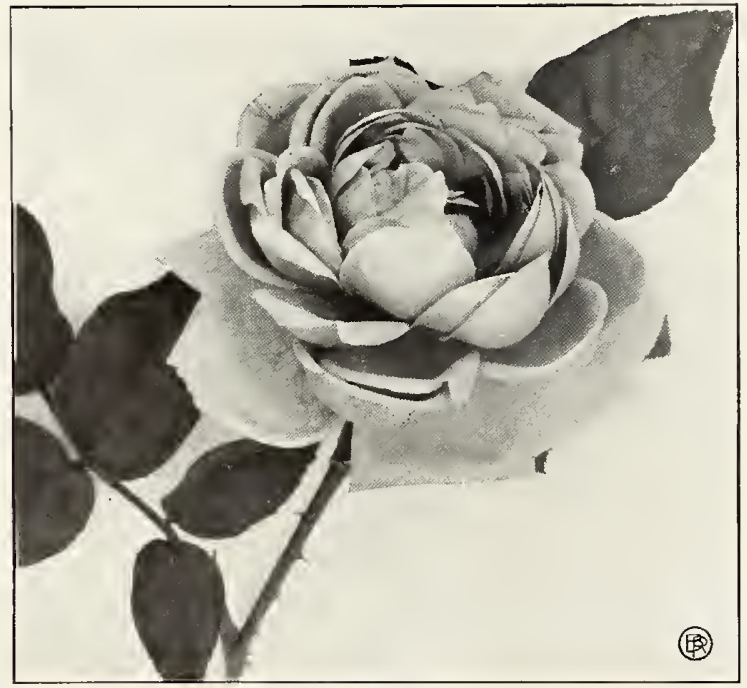

Sunburst
GEORGE DICKSON. (H. P.) This is one of the darkest red roses grown. It was introduced by Alex. Dickson \& Sons, who claim it to be the best rose ever raised by them, and was named after the senior member of their firm, now over eighty years of age. The color is descrihed by them as a velvety black-crimson, the backs of the petals bcing heavily veined with deep, pure crimson-maroon.

2 yr., 50c; X-size, 75c each.

HADLEY. (H. T.) Introduced hy the Montgomery Co., of Hadley, Mass. In color it is a deep, velyety crimson, retaining its brilliancy, and in fragrance it is excelled only by American Beauty. It is a strong, rapid grower, the flowers borne on long stiff stems.

2 yr., 50c; X-size, $75 \mathrm{c}$ each.

HIS MAJESTY. (H. P.) This is the "Crimson Frau KarI Druschki," and classed by some as a Hybrid Tea. Its blooms are full, of great size, with high pointed centres, and have wonderful substance and depth of petal. Its color is deep, dark crimson, shaded with dcep vermilion-crimson toward the edges. It is one of the sweetest-perfumed roses in cultivation. Awarded gold medal by the National Rose Society of England in 1908.

$$
2 \text { yr., 50c each. }
$$

HOOSIER BEAUTY. (H. T.) A rose that has been instantly popular wherever it has been seen. In color it is a gowing crimson-scarlet with darker shadings. The bud is of good length, and opens into a magnificent bloom, quite dazzling in velvety brilliance. It is as fragrant as Richmond; has more petals, a stiffer stem, a texture like velvet. 1 yr., $50 \mathrm{c} ; 2$ yr., $75 \mathrm{c} ; \mathrm{X}$-size, $\$ 1.00$

KILLARNEY BRILLIANT. (H. T.) This is the newest member of the Killarney family and is the best of the Kiliarney type. It has the same habit of growth and the same freedom of bloom as its parent, while the flower is more double. The color is a very brilliant pink and varies like Killarney. In the garden in hright weather it is clear pink, and in dull weather ahmost crimson. Extra good.

2 yr., 50c; X-size, $75 \mathrm{c}$.

MME. EDOUARD HERRIOT (The Daily MaiI Rose). (A. B.) Few roses have been so much talked ahout during the past two years. At the greatest horticultural exhibition ever held, in competition with world's greatest rosarians, 11. Pernet Ducher was awarded the gold cup offered by the London Daily Mail, for the best new rose. It was also exhibited in London at the exluibition of the NationaI Rose Society of England, where it was awarded the society's gold medal. The originator describes its color as follows: "Buds coral-red, shaded with yellow at the base; the open flower of medium size, semi-double, of a superb coral-red shaded with yellow and bright rosy scarlet, passing to shrimp-red." The bud is long, slender and pointed, the color is like sunshine on a copper-red metal. 2 yr., $50 \mathrm{c} ; \mathrm{X}$-size, $75 \mathrm{c}$ each.

RADIANCE. (H. T.) A rose much sought after by lovers of good roses. A brilliant rosy-carmine, displaying rich opaline-pink tints in the open flower, which is large, fuIl and of fine form, with cupped petals. It blooms constantly and is delightfully fragrant.

2 yr., 50c; X-size, $75 \mathrm{c}$.

SUNBURST. (H. T.) This magnificent yellow rose has been steadily gaining friends ever since it was introduced by Pernet Ducher in 1912. It is a fine bedding rose, producing flowers on strong upright stems suitahle for cutting. The color is orange-copper or golden-orange and golden-yellow. It is the yellowest of all roses of the everblooming class. If you want something worth while, get Sunburst.

2 yr., 50c; X-size, 75e. 


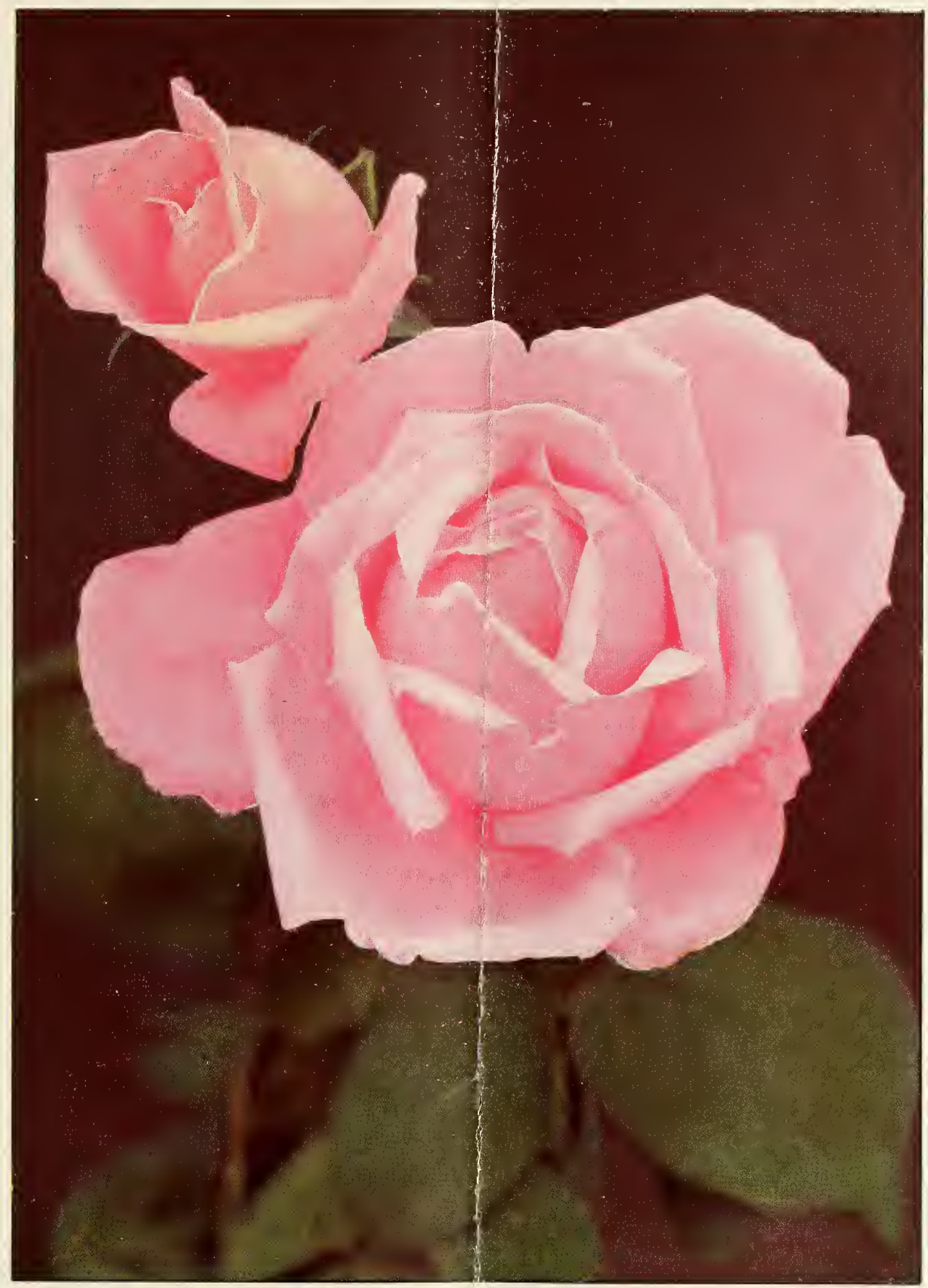

MADAME CAROLINE TESTOUT

A rose well known in the far-famed street plantings of the Pacific eoast. and an equally valuable hardy acquisition to our own New England gardens. It grows vigorously, bearing large, cup-shaped, satiny pink flowers which show a silvery touch at the edges of the petals. Supplied in both bush and elimbing form. (See pages 9 and 13.) 


\title{
DEPENDABLE DESCRIPTIONS
}

\author{
ALPHABETICALLY ARRANGED
}

\section{SIZES AND PRICES}

"Field" plants are budded stock, dormant; "Pots, 2 y'r" are own-root roses, from four and five-inch pots; "Pots, X-size" are selected stock from six-inch pots or larger, budded. Dormant plants not supplied after May first.

$\begin{array}{rrrrr}\text { Varieties listed at } 35 \mathrm{c} \text {, furnished for } \$ 3.50 \text { per doz.; } & \$ 25.00 \text { per } 100 . \\ 50 \mathrm{c} & & 5.00 & 40.00 & \\ 75 \mathrm{c} & \$ 4 \text { per } 6 ; & 7.50 & 60.00 & \end{array}$

Not less than 6 at the dozen rate; not less than 25 at the 100 rate.

\section{ABBREVIATIONS}

A.B., dustrian Briar
B., Bourbon
C.T., Climbing Tea
C.H.T., Cl. Hybrid Tea
C.P., Climbing Polyanth.

C.P., Climbing Polyantha

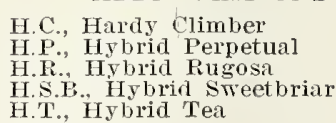

H.P., Hybrid Perpetua

H.T. Hybrid Tea
H.S B Hybrid Swetbria

\author{
H.W., Hybrid Wichuraiana \\ M., Moss \\ P., Polyantha \\ T., Tea \\ W., Wichuraiana or Memorial
}

AgLAIA-(See Yellow Rambler.)

ALEXANDER HILL GRAY-(T.) Deep lemonyellow, similar in color to Marechal Niel. Large, full flowers with high pointed ccnter and perfect form, freely produced and strongly tea perfumed.................

ALFRED COLOMB - (H.P.) Cherry-crimson; large slobular flowers; an erect grower and abundant bloomer.............. \$0.35

ALICE ALDRICH-(H.R.) A remarkably fine bush rose for the garden. Large, double, clear pink flowers, borne at intervals during the whole season. One of the finest of the rugosa type...............

AMERICAN BEAUTY-(H.P.) Grandly beautiful in size, form and color. Rich red, passing to crimson, very delicately veined

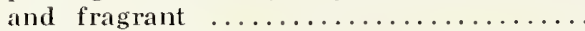

AMERICAN PILLAR-(H.C.) Large, single flowers of rich rosy-pink, approaching brilliant carmine, and golden-yellow stamens. Grows thick, vigorous canes and broad dark green leaflets, tough, shining and insect-proof. $A$ new and valuable climber originated by the U. S. Government Department of Plant Introduction..

AMY ROBSART-(H.S.B.) Deep rose, vig-

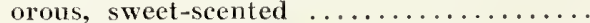

ANNE OF GEIERSTEIN - (H.S.B.) Dark crimson. Same form as Amy Robsart...

ANNE de DIESBACH or Glory of Paris(H.P.) A lovely shell-pink; long pointed buds, very large petals and large, finely formed, compact flowers, very full and double; sweetly fragrant. A vigorous

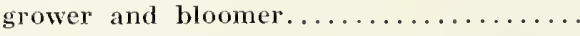

ANNY MUELLER-(P.) Brilliant, shining pink flowers in profusion, with long petals, gracefully curved and slightly twisted, Splendid for bedding and dwarf hedges; everblooming and hardy...............

ANTOINE RIVOIRE-(H.T.) Creamy-white, delicately tinted with pink; extra large petals, making a bloom of decidedly distinct and beautiful form; full and double

.35

.50
ARTHUR R. GOODWIN-(A.B.) See "Roses

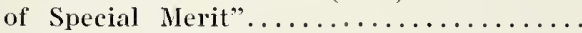
AVIATEUR BLERIOT-(H.W.) Saffron-yellow with golden-yellow center; full, medium size, flowering in elusters...........

BABY DOROTHY - (See Maman Levavasseur.)

BABY RAMBLER - (See Mme. Norbert Levavasseur.)

BABY TAUSENDSCHON-(See Louise WeI-

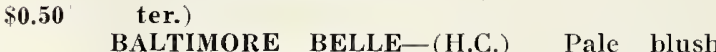
passing to white, very double flowers in beautiful clusters, making a perfect mass of bloom; one of the very best climbers. $\$ \mathbf{\$ 0 . 3 5}$

BARON de BONSTETTEN-(H.P.) Rich velvety maroon; large, full. A splendid sort.

BARONESS ROTHSCHILD - (H.P.) Light pink; cupped form, very symmetrical, without fragrance. Very distinet and beautiful exhibition variety. Very hardy

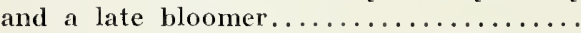

BARDO JOB-(H.T.) Rich, brilliant velvety crimson. Very hardy and a profuse

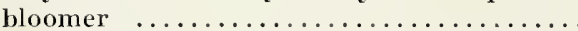

BESSIE BROWN-(H.T.) Of a distinet type in shape and color. Erect stems; full, deep blooms with enormous petals; white, flushed with pink, growing deeper toward

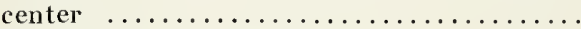

Field Pots Pots y'r $2 y^{\prime} r$ X-size

$\$ 0.50 \$ 0.75$

.50

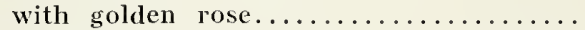
BLANC de COUBERT - (H.R.) A fine hybrid rugosa. Flowers pure white, semi-double, fragrant $\ldots \ldots \ldots \ldots \ldots \ldots \ldots \ldots \ldots \ldots \ldots \ldots$ BLUE RAMBLER - (See Veilchenblau.)

BRITISH QUEEN - (H.T.) See "Roses of

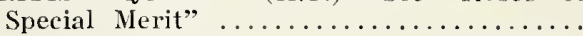

CAPTAIN HAYWARD-(H.P.) Bright searlet, very vivid in summer and glowing in autumn. Large, full and bold; flower of

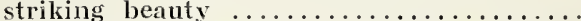

CATHERINE ZEIMET or White Baby Rambler-(P.) Pure snow-white double blooms in profuse clusters, making a sheet of white color, with a fragrance similar to Hyacinths. A compact, bushy grower of dwarf habit; foliage dark, glossy and finely cut; ever-blooming and hardy.........
.35

.50 


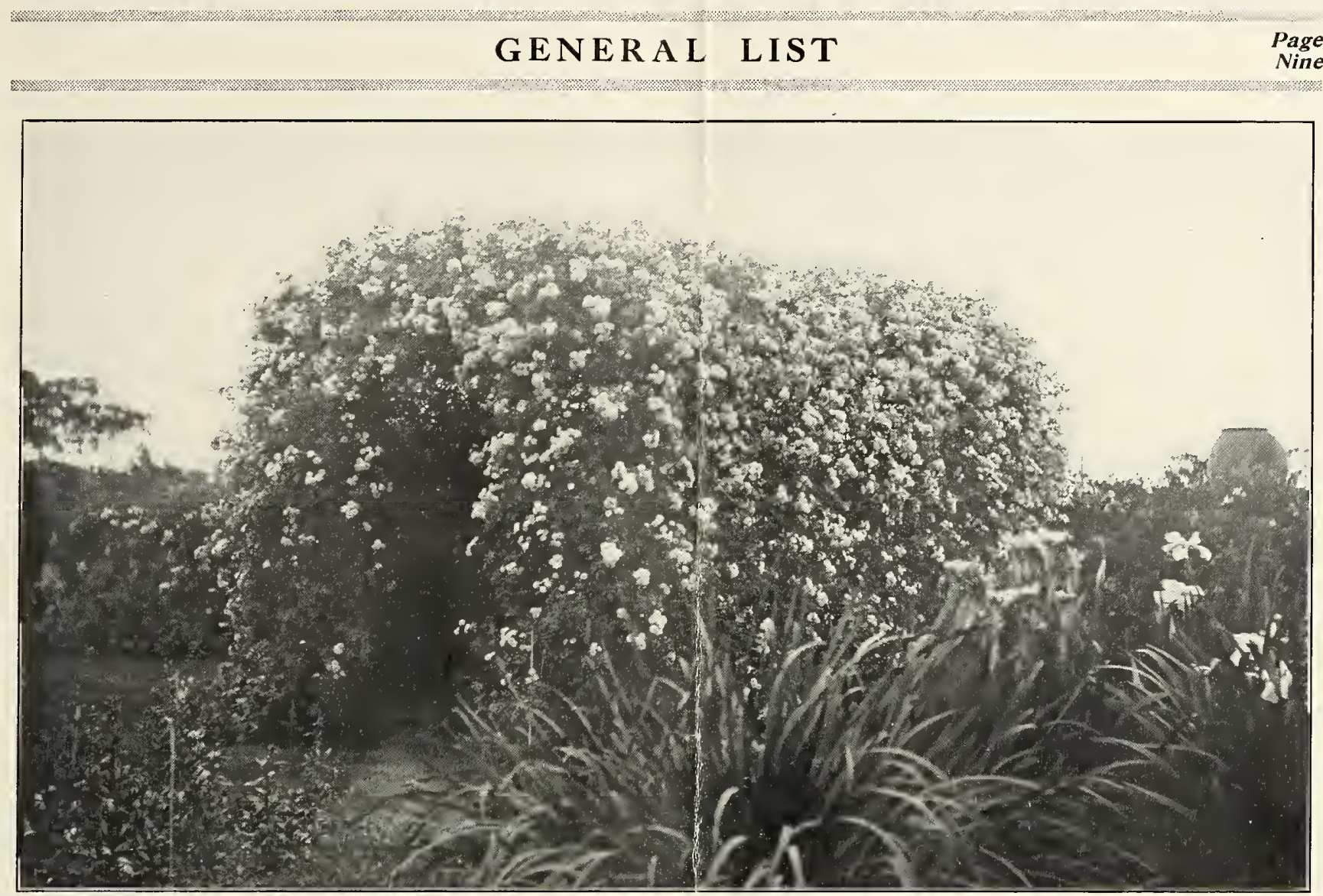

“DOROTHY PERKINS" covers this arbor with a smother of bloom

Field Pots Pots

CHARLES DINGEE - (See Wm. R. Smith.) 2 y'r 2 y'r X-size

CHRISTINE WRIGH'T-(H.C.) New. Bright, clear wild-rose-pink flowers, 3 to 4 inches in diameter. Double, beautiful in bud, and

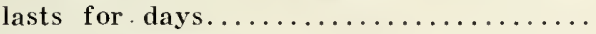

CLARA WATSON-(H.T.) Flesh, with center tinted rose-peach. Good form and rich fragrance $\ldots \ldots \ldots \ldots \ldots \ldots \ldots \ldots \ldots \ldots$

CLIMBING AMERICAN BEAUTYY-(H.C.) A seedling from American Beauty. Same as its namesake in size, color and fragrance, with the addition of the climbing habit. Better hlooming qualities, good foliage; it has proven hardy, and able to withstand

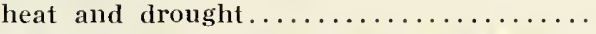

CLIMBING BABY RAMBLER-( See Miss G. Mesman.)

CLIMBING ETOILE de FRANCE-(C.H.T.) In color and fragrance the same as Etoile de France, with the climbing habit.......

CLIMBING GRUSS an TEPLITZ-(C.H.T.) Vivid fiery crimson, an exact duplicate of the bush rose of this name, except that it is a vigorous climber, producing a sheet of dazzling bloom. Superb for a pillar rose..

CLIMBING HELENE GAMBIER - (C.H.T.) Flower opens orange-yellow, changing to coppery-yellow. A good grower..........

CLIMBING HELEN GOULD - (C.H.T.) Warm watermelon-red, same in color as its par-

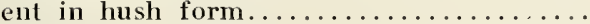

CLIMBING KAISERIN - (See Mrs. Robert Peary.)

.50
CLIMBING KILLARNEY-(C.H.T.) A vigor ous climber, otherwise possessing all of the splendid qualities of the parent líl-

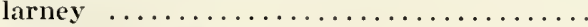

CLIMBING LIBER'TY-(C.H.T.) Color bright velvety crimson; fills a long-felt want for a good red climher.

CLIMBING MADAME CAROLINE TESTOU'T -(C.H.T.) Beautiful glowing pink, identical in flower with its parent namesalie; a rampant climber

CLIMBING RICHMOND-(C.H.T.) Brilliant scarlet-red. A sport from the well-known .75 bush variety and bound to become popular CLIMBING SOUVENIR of WOOTTON-(C.H. T.) Velvety red; same in bloom as the bush Wootton, from which it is a sport; a strong, rampant climber, profuse with splendidly formed flowers.............

CLIMBING VISCOUNTESS FOLKESTONE(See Gainsborough.)

CLIO-(H.P.) A vigorous grower producing handsome foliage; large globular flowers of flesh color, shaded to the center with rosy-pink. Similar to Margaret Dickson..

CLOTHILDE SOUPER'T - (P.) A really wonderful Rose for bedding-out or for pot culture; medium size and rery double; white, shading to deep pink at center. A profuse bloomer and a strong dwarf grower, deliciously fragrant $\ldots \ldots \ldots \ldots \ldots \ldots \ldots \ldots$
Field Pots Pots .50 


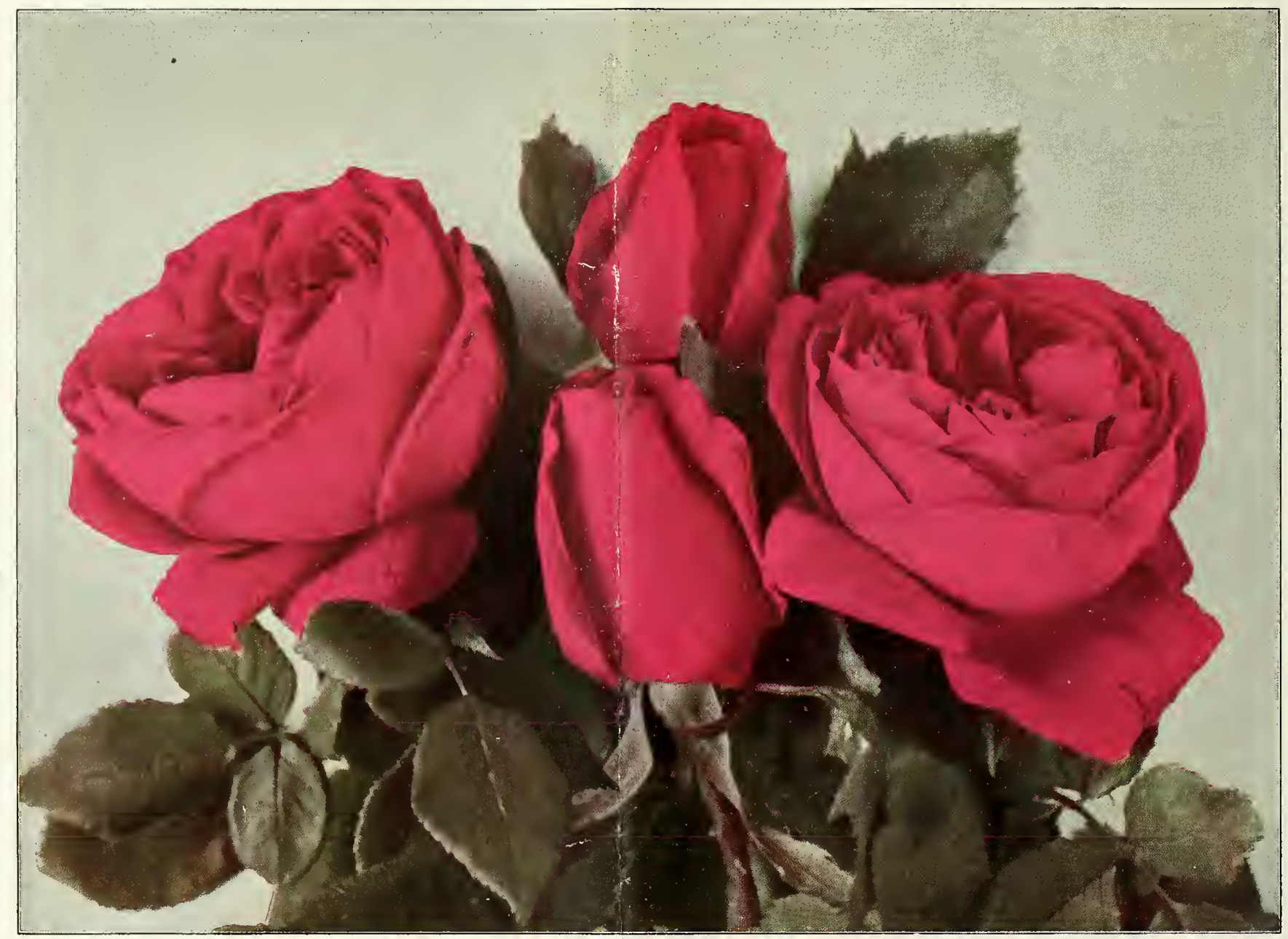

ULRICH BRUNNER

A brilliant eherry-red rose deriving its immense size and full form from Paul Nevron, its parent. (See page 16.)

Fíeld Pots Pots
$2 y^{\prime} y^{\prime} y^{\prime} \mathbf{X}-$ size

COLLEEN - (H.T.) Brilliant rose, shaded rose-pink, with deeper rose-erimson veneering on a distinet creamy-yellow ground, non-fading. Full, with enormous petals and high pointed eenter, forming a most magnifieent flower. Free blooming, sweet scented, splendid for bedding, pot

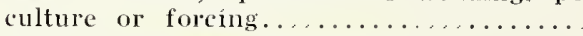

CONRAD FERDINAND MEYER-(H.R.) PUre, silvery-pink, surpassing all others of the Rugosa family in beauty of color and fullness of form; fragrant and hardy.........

COUNTESS OF GOSSFORD - (H.T.) Clear salmon-pink, base of petals suffused with yellow. Large well-formed flowers.......

COUNTESS OF SHAFTSBURY - (H.T.) Bright silvery-earmine, mottled and flushed pale shell-pink at the edges of the petals, giving a delightful picotee effect. Ipright, vigorous, of free branehing growth. The

.75

,

finest of all pink Roses for bedding, massing and garden deeoration.............. CRESTED MOSS-(Ml.) Deep pink in lud, with mossy fringe and erest...........

CRIMSON BABY RAMBLER (See Mme. N. Levavasseur.)

CRIMSON QUEEN-(H.T.) A strong, upright grower with flower large and full. Color a rich bright velvety crimson. A grand rose, always in bloom..........

CRIMISON RAMBLER-(C.P.) The most popular out-of-door elimber of today; rieh clusters of bloom form a mass of vivid crimson beanty. Perfeetly hardy in the most

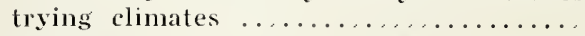

DAILY MAIL ROSE-(See Mme. Edouard Herriot.)

DEAN HOLE (H.T.) Light carmine, shaded rose, flushed with old gold at base of petals. Large, full and long-pointed flower..
Field Pots Pots y'r 2 y'r $\mathrm{X}$-size 
Field Pots Pots

DEBUTANTE-(H.W.) Light pink, passing to white; double hlooms in clusters, with delicate odor of the Sweetbriar; dark, glossy foliage; suited for climbing or trail-

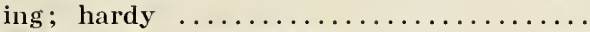

DOCTOR W. VAN FLEET-(H.W.) A delicate shade of flesh-pink, deepening to rosyflesh in the center; buds pointed, flowers full and douhle, open to an immense diameter, sweetly perfumed. Beautiful bronzegreen foliage $\ldots \ldots \ldots \ldots \ldots \ldots \ldots \ldots \ldots$

DOROTHY PAGE ROBERTS-(H.T.) Coppery-pink, suffused with apricot yellow. Very free and constant bloomer. A good

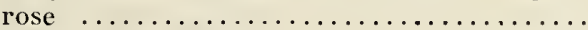
DOROTHY PERKINS-(H.W.) A very popular pink climber. Beautiful shell-pink color, which holds for a long time, fading finally to a lovely deep rose; very sweetscented $\ldots \ldots \ldots \ldots \ldots \ldots \ldots \ldots \ldots \ldots \ldots$

DUCHESSE de BRABANT-(T.) Exceptionally healthy, vigorous and productive; large, full, beautiful in bud and bloom; highly fragrant; soft, light rose, with heavy shading of amber-salmon..........

DUCHESS OF ALBANY or Red La France(H.T.) Two shades darker than its parent, the La France, of which it is a duplicate in

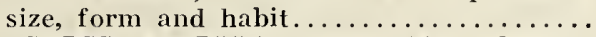

DUCHESS OF WELLINGTON- (H.T.) intense saffron-yellow, stained with deep crimson, deepening with the development of the flower to a coppery-yellow of a distinctly

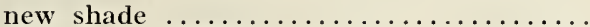

EARL OF DUFFERIN-(H.P.) Rich, brilliant, velvety crimson, shaded with dark maroon; large, full, finely formed; delightful fragrance. A vigorous grower........

ECARLATE-(H.T.) Scarlet-red of extreme brilliancy, higher in color than "Liberty" and "Richmond"; medium size, fair form, very floriferous, a splendid bedder.......

EDITH PART - (H.T.) Rich red, suffused with deep salmon and coppery-yellow. Perfectly built flowers of good substance; vigorous, free blooming and of beautiful habit, very sweetly perfumed. A superb

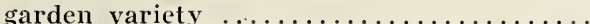

EDWARD MAWLEY-(H.T.) Velvet-crimson of a deep, rich color on huge petals beautifully arranged. See "Roses of Special

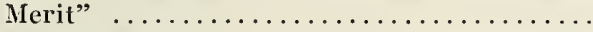

ERNA TESCHENDORFF-(P.) Carmine-red sport from and fuller than Mme. Norhert Levavasseur, of fiery color similar to Gruss an Teplitz; never blues. Blooms from May to end of October. Claimed the newest and best of the Baby Rambler class; a medal winner $\ldots \ldots \ldots \ldots \ldots \ldots \ldots \ldots$

ETOILE de FRANCE or Star of France(H.T.) A brilliant shade of clear redcrimson velvet, centering to vivid cerise; large flowers on long, stiff stems; remarkably vigorous, free-blooming and hardy. lts chief value lies in its striking beauty as an outdoor bloomer and bedder. Bronzy-

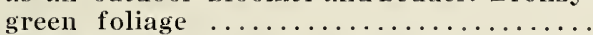
EUPHROSYNE - (See Pink Rambler.)

EVANGELINE-(H.WV.) One of WValsh's new climbers of merit. Flowers white tipped with pink. A strong grower with good

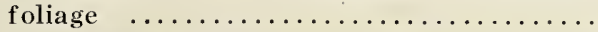

$2 y^{\prime} r 2 y^{\prime} r$ X-size
Field Pots Pots

EXCELSA or Red Dorothy Perkins-(H.W.) Intense crimson-scarlet, double flowers in brilliant clusters set in glossy, shining foliage which never mildews nor spots. Extremely vigorous and the handsomest of

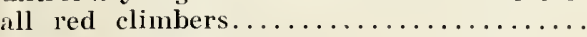

FISHER HOLMES-(H.P.) Scarlet-crimson; very rich and beautiful..............

EVERGREEN GEM-(H.W.) Foliage nearly evergreen. Flowers double, rich bromze color $\ldots \ldots \ldots \ldots \ldots \ldots \ldots \ldots \ldots \ldots \ldots \ldots \ldots \ldots \ldots \ldots \ldots \ldots$

FI.ORA MeIVOR - (H.S.B.) Flowers pure

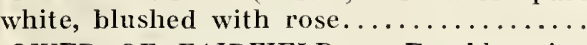

Fl,OWER OF FAIRFIELD or Everblooming Crimson Rambler-(H.C.) Brilliant crimson, base of petals white; flowers perpetually and profusely in brilliant clusters from early summer until frost............ FRANCIS SCOTT KEY-(H.T.) Red, shading to cerise. See "Roses of Special Merit"...

FRANCESCA KRUGER - (H.T.) Copper, shaded peach; good size, very free and constant bloomer

FRAU KARL DRUSCHKI. The White American Beauty or Snow Queen-(H.P.) An everywhere hardy, vigorous grower, with bright green leaves, delicately veined; splendid long buds and magnificent snowwhite blooms with large saucer-shaped petals. Rightly named and deservedly a prizeGAINSBOROUGH-(C.H.T.) Delicately tinted fawn, almost white, with a satiny luster; very large flower, resembling a white,

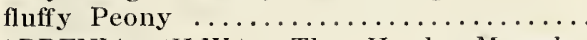

GARDENIA-(H.WV.) The Hardy Marechal Neil. Deep, rich golden yellow flowers, passing to creamy white. Blooms profusely and is as hardy as an oak.........
GENERAL JACQUEMINOT - (H.P.) Handsome blooms of bright, shining crimson, rich, brilliant, velvety and fragrant. Everybody knows and wants the "Jack" for its all round $\operatorname{good}$ qualities............. $\mathbf{. 3 5}$

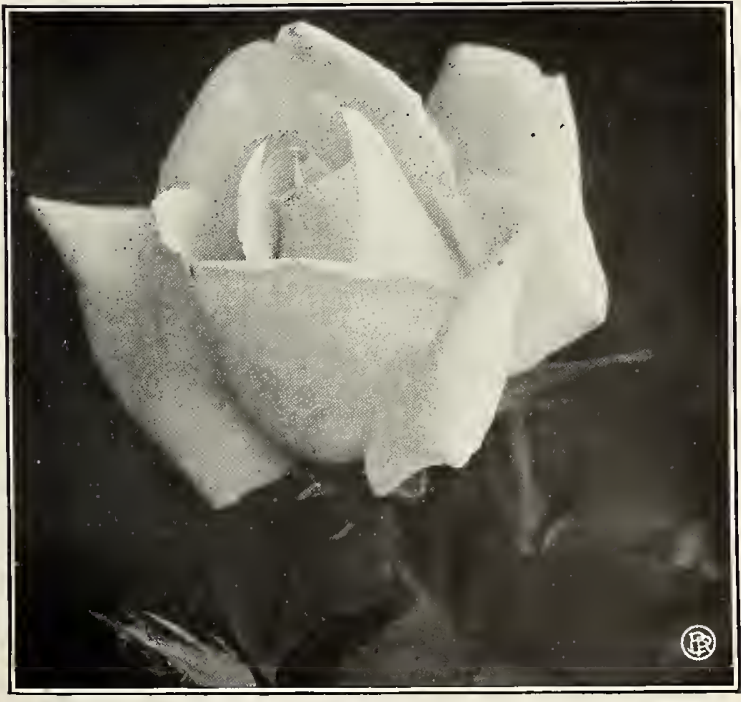

Frau Karl Druschki 


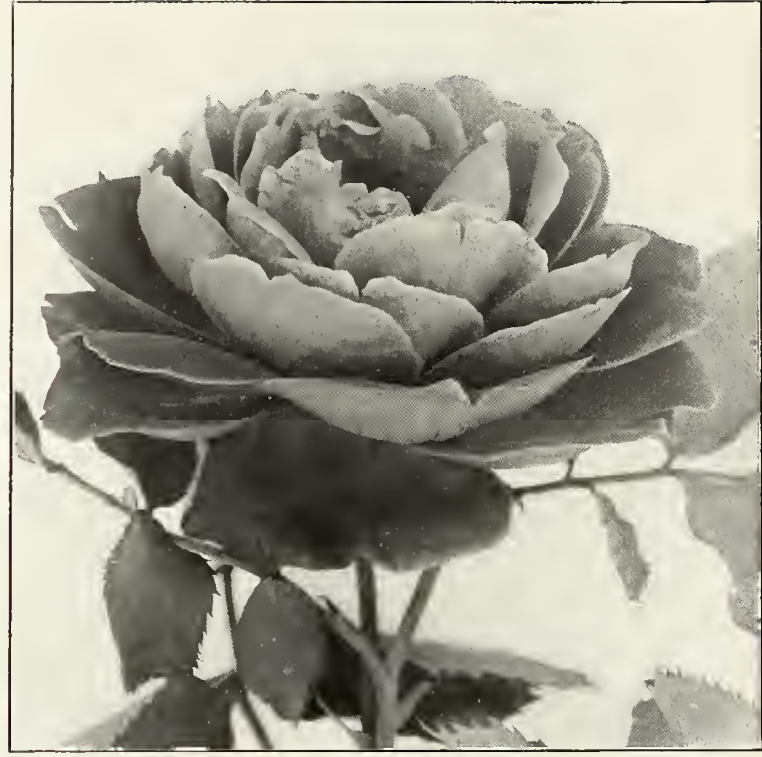

Gruss an Teplitz

Field Pots Pots

GENERAL MacARTHUR-(H.T.) Vivid crimson-scarlet, the most beautiful shade of any garden or forcing Rose offered; free from mildew ....................

(H.T.) Glowing deep carmine-red; large, full and fragrant flowers carried erect on stiff, robust stems; vigorous, compact and continually blooming ...............

GEORGE ARENDS or Pink Druschki-(H.P.) Bright red-carmine to delicate rose; extremely large, full and deliciously scented, very floriferous. Long, stiff stems; highly recommended. See "Roses of Special Merit"

GEORGE C. WAUD (H.T.) Orange-vermilion; remarkably distinct and beautiful... GEORGE DICKSON-(H.P.) Dark crimson. See "Roses of Special Merit".............50

GLOIRE de DIJON-(C.T.) Buff, orangc-yellow center, large and full...

GLOIRE LYONNAISE-(H.P.) Creamy-white; the nearest yellow Hybrid Perpetual Rose,

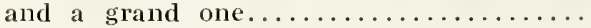

GRUSS an TEPLITZ (Greeting to Teplitz) or Virginia R. Coxe-(H.T.) Hardy in all sections; grows freely; vivid, dazzling, ficry crimson; sweetly fragrant; produces a mass of gorgeous blooms on long stems..

HADLEY - (H.T.) Deep, rich, velvety erimsom. See "Roses of Special Merit".......

HARRY KIRK-(H.T.) Deep, sulphur yellow, with edges of petals lighter. Well-formed, full, free and vigorous. . . . . . . . . .

HELEN GOULD - (H.T.) An incessant grower and bloomer, hardy everywhere. Long, beautiful buds and full, double flowers of warm, rosy-crimson, resembling a red, ripe

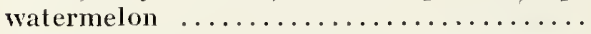

HERMOSA-(B.) Popular for many years; cup-shaped, finely formed, full flowers of soft, deep pink; ever-blooming, beautiful

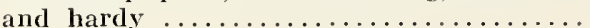

.50
HELENE GAMBIER-(H.T.) Flower opens Field Pots Pots 2 y'r 2 y'r X-size orange yellow, changing to coppery yellow, and then outer petals to lemon-yellow...

HERZOGIN MARIE ANTOINETTE-(H.T.) Flowers large, full and of splendid form. Color deep coppery-yellow. The finest yellow rose $\ldots \ldots \ldots \ldots \ldots \ldots \ldots \ldots \ldots \ldots$

HIAWATHA - (H.W.) Glowing ruby-crimson, with a clear white eye; single flowers in clusters; light glossy green foliage. A seedling from Crimson Rambler, excellent for climbing, trailing or forcing.........

HIS MAJESTY--(H.P.) Darls crimson. See "Roses of Special Merit"..............

HOOSIER BEAUTY-(H.T.) Glowing crimson-scarlet with darker shadings. See "Roses of Special Merit"..............

HUGH DICKSON-(H.P.) Brilliant crimson, shaded scarlet; very large and beautiful in form, with large, smooth petals, slightly reflexed on the edges. A vigorous grower, with handsome foliage; very fragrant....

IRISH ELEGANCE-(H.T.) Old gold, coppery-yellow, flamed with ruddy crimson. Large single flowers, strongly and deliciously tea-perfumed and never out of bloom $\ldots \ldots \ldots \ldots \ldots \ldots \ldots \ldots \ldots \ldots \ldots$

J. B. CLARKE-(H.T.) lntense scarlet, shaded crimson-maroon, very dark and rich, and sweetly fragrant; foliage bronzygreen changing to dark green; growth strong and upright, making a large, hand-

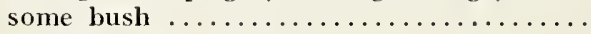

JESSIE-- (P.) Bright, cherry-crimson, likened unto Richmond in color and non-fading; claimed to excel all red Baby Ramblers in beauty of color. Splendid for pot culture, bedding and massing; blooms constantly

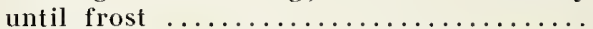

JOHN HOPPER-(H.P.) Bright rose with carmine center; large and full. A profuse bloomer and a standard sort............

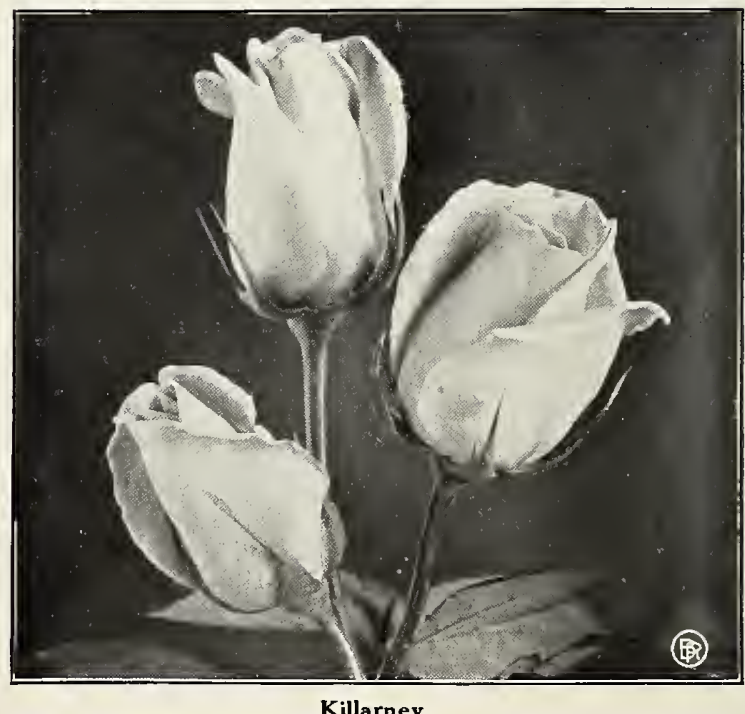


JONKHEER J. L. MOCK-(H.T.) Clear imperial pink, reverse of petals rosy, silverywhite; blooms of magnificent size and form, produced freely on stiff, erect canes; the strongest grower in the Hybrid Tea class. Awarded two gold and one silver medals and five first prizes in Europe.....

JOHANNES WESSELHOFT - (H.T.) Color clear lustrous yellow. Growth very much like Kaiserin ......................

JULIET-(A.B.) Outside petals old gold, interior rich rosy red. Strong, upright

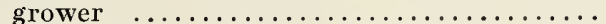

JOSEPH HILL-(H.T.) Saffron-yellow, outside petals coppery. Full deep flower of

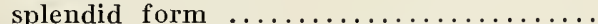

KAISERIN AUGUSTA VICTORIA - (H.T.) Pure white, does not "pink" when planted out; splendid large buds and superb, full, double blooms, making the choicest cut flowers. A most sturdy grower, blooming steadily from early spring until late frost

KILLARNEY or Irish Beauty-(H.T.) Brilliant sparkling pink with large, pointed buds, broad, wax-like petals with silvery edges and enormous semi-full flowers of

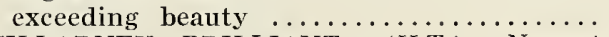

KILLARNEY BRILLIANT - (H.T.) Newest member of its family. Color bright, true pink, brilliant throughout the year. As free a producer as the parent, and a trifle

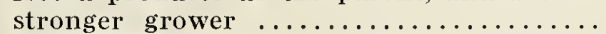

La DETROIT-(H.T.) Shell-pink, shading to soft rose. Large, full, upright and strong.

LADY ALICE STANLEY-(H.T.) Outside of shell-shaped petals deep coral-rose, inside delicate flesh, often suffused with bright flesh. A vigorous grower of free branching habit, with beautiful foliage and a large, full, well-formed, fragrant flower ou every

shoot throughout the season..............
LADY BATTERSEA or Red Niphetos-(H.T.) Lovely wine-red; very long, pointed buds and large, full and double blooms.........

LADY GAY-(H.W.) Cherry-pink, fading to soft white; the flowers, in large, loose trusses, together with the buds and foliage, form a mass of beauty from base of vine to tips of branches; a perfectly hardy

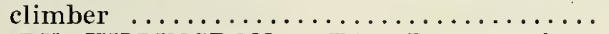

LADY HILLINGDON - (T.) Deep apricotyellow to orange; long, pointed buds; very free-flowering, and a striking decorative rose. Awarded gold medal of National

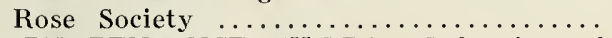

LADY PENZANCE-(H.S.B.) Soft tint of copper, with yellow base..............

La FRANCE-(H.T.) Silvery-rose, with pink shades and satin-like petals of umsurpassable beauty; large, symmetrical and deliciously fragrant blooms from June until frost; hardy with protection............

La PROGROSSE-(H.T.) Color nankeen-yellow with golden-yellow buds. Cupped form, opening large..................

La REINE - (H.P.) Clear, bright rose; beautiful in color and form; deservedly called

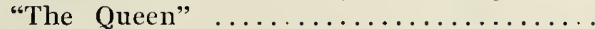

LAURENT CARLE-(H.T.) Brilliant velvety carmine, with long buds borne on long stems. An extremely vigorous grower, with splendid dark green foliage..........
Field Pots Pot
y'r 2 y'r X-size
Field Pots Pots

LCRD PENZANCE-(H.S.B.) Soft shade of fawn, passing to yellow in center....... .35

LOUISE WELTER or Baby Tausendschon(P.) Small cupped blooms of veined rose with feathered edges of soft clear pink. A lovely little novelty, each bush forming a

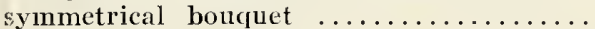

LUCY BERTRAM-(H.S.B.) Deep crimson

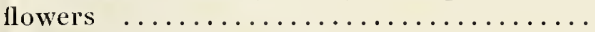

MADAME ABEL CHATENAY-(H.T.) A good grower and perpetual bloomer; large and beautiful in bud and bloom; deep, recurved petals of rose-pink, with a tinge of salmon

MADAME CAROLINE TESTOUT - (H.T.) Brilliant satiny-rose, deepening at center and bordered with silvery-rose; immense broad petals and extremely large flowers.

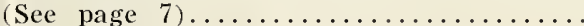
ADAME EDOUARD HERRIOT or Daily
Mail Rose-(H.T.) Coral-red with shades of yellow. See "Roses of Special Merit".

MADAME GABRIEL LUIZET-(H.P.) Pink, distinct, very large, cupped-shaped; somewhat fragrant. One of the choicest......

MADAME GEORGE BRUANT - (H.R.) A free flowering white variety with semi-

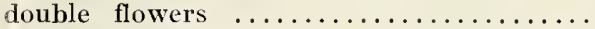

MADAME JENNY GUILLEMOT-(H.T.) Deep saffron-yellow, opening canary with dark golden shadings; buds long and pointed; petals and blooms immense............

MADAME JULES GROLEZ-(H.T.) Bright china rose; large, full and perfect form; very floriferous; splendid for bedding and

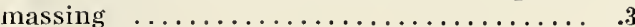

MADAME LEON PAIN-(H.T.) Silvery fleshpink, center yellowish orange, large, full

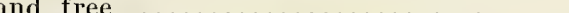

MADAME M. BRAMBERSON-(H.T.) Soft shell-pink, full, large and constant.......

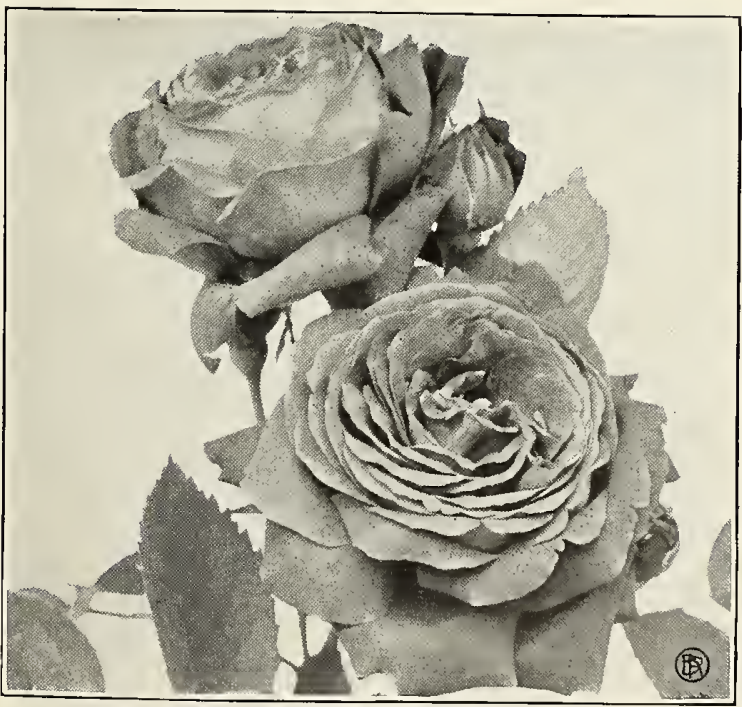

Magna Charta 
Field Pots Pots
2 y'r 2 y'r $x-s i z e$

MADAME NORBERT LEVAVASSEUR or Baby Rambler-(P.) The Crimson Rambler in dwarf form, with the same clear, brilliant, ruby-red color. Hardy and hcalthy everywhere, attaining a height of twenty inches. It blooms in profuse clusters until frost, and then throughout win-

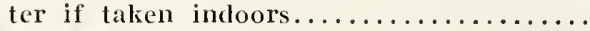

MADAME PERNET DUCHER - (H.T.) Canaryyellow with deep center. Very free and strong $\ldots \ldots \ldots \ldots \ldots \ldots \ldots \ldots \ldots \ldots \ldots$

MADAME PLANTIER-(H.P.) A Jume rose, well worthy of its long and continued popularity. Pure white, large and double; hardy as a forest tree................

MADAME RAVARY-(H.T.) Long pointed buds of beautiful solden-yellow, opening to large, full, orange-yellow flowers. Similar to Testout in growth and habit; free flowering; the most popular yellow liose in Europe . . . . . . . . . . . . . . . .

MADAME SEGOND WEBER-(H.T.) ROSy salmon, decpening in color as its long, pointed buds open and expand into bloon:s of enormous size; petals of heavy texture

and beautiful in form..................
MAGNA CHARTA-(H.P.) Extra large, full flowers of unusual depth; sweet and of fine form; bright rosy-pink in color; one of the hardiest and hest bloomers.........

MAMAN COCHET-(T.) Rich, rosy-pink, shaded silvery-rose on outer petals; exquisite in color and graceful in form from bud to bloom, and delightfully fragrant...

MAMAN LEVAVASSEUR, Baby Dorothy or Pink Baby Rambler-(P.) A prolific producer of pure pink flowers, with all of the good qualities of Crimson Baby Rambler..

MANDA'S TRIUMPH-(H.W.) Pure white, well-formed, double flowers in clusters; sweetly scented; an entirely hardy climber

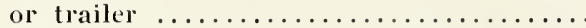

MARECHAL NIEL-(C.T.) Climbs to a great height and yields beautiful golden-yellow buds and blooms in rich profusion, with a fragrance peculiar to the Marechal Niel

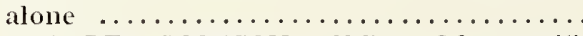

MARGARET DICKSON-(H.P.) Of magniticent form, with large shell-shaped petals of great substance. White, with pale flesh center; fragrant; foliage large and dark

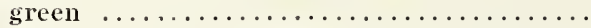

MARSHALL P. WILDER-(H.P.) Deep, rich, glowing red; extra large, semi-globular and full; a very strong grower and free

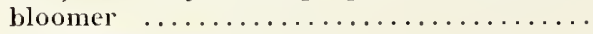

MEG MERRILIES - (H.S.B.) Large crimson

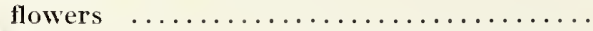
MELODY - (H.T.) Deep canary-yellow changing to primrose at edges. Mcdium size,

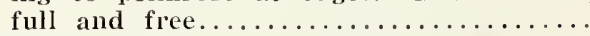

MEMORIAL ROSE-(See Wichuraiana.)

METEOR-(H.T.) lntense velvety crimson, elegantly formed, fully double and borne on long stems. Healthy, bright foliage of

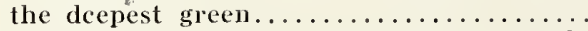
MILADY - (H.T.) In color similar to Richmond, yet richer and darker in the bud. Form and fragrance resembles Gell. Jacqueminot. Of sturdy habit, splendid foli-

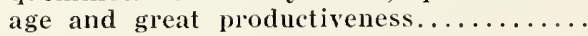

M1SS ALICE de ROTHSCH1LD-(T.) Rich, deep citron-yellow, which intensifies as the bloom expands. The flowers are large, full and of perfect form, with high pointed center, the petals charmingly reflex.......

MISS G. MESSMAN-(C.P.) Climbing Baby Rambler, a true ever-blooming Crimson Rambler; a climbing sport from the original Crimson Baby Rambler Mlme. Norbert Levavasseur. The combination of color and habit make this a most desirable Rose

MRS. AARON WARD-_(H.T.) A most striking color-lndian-yellow shading to lemoncream at edges of petals. Very large and full, of refined form. Conceded to be a

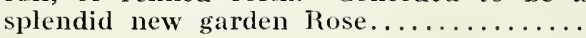

MRS. ARTHUR ROBERT WADDELL-(H.T.) Long and pointed buds of rosy-scarlet, .35 .50 ble and extremely showy.............

MRS. GEORGE SHAWYER - (H.T.) Brilliant rose-pink, or bright peach-pink. Flowers large, well formed, fairly full, with petals

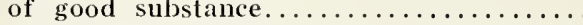

MRS. JOHN LAING-(H.P.) A beauty in clear, bright, shining pink; each hud in its long, serrated calyx with adjacent green foliage, forms a dainty and lóvely boutonniere; immense, full blooms on long, stiff stems; sweetly scented..............

MRS. R. G. SHARMAN-CRAWFORD-(H.P.) .35 .50 Light flesh-pink; large, perfect flowers of imbricated forn, on clean, erect stems....

MRS. ROBERT PEARY or Climbing Kaiserin -(C.H.T.) lvory-white, identical with the parent Kaiserin Augusta Victoria, except in its strong climbing habit.............

MISTRESS T. HILLAS-(H.T.) Pure chromeyellow, large and full; very free and perpetual; a vigorous grower with few and small thorns; a fine garden and exhibition Rose $\ldots \ldots \ldots \ldots \ldots \ldots \ldots \ldots \ldots \ldots$

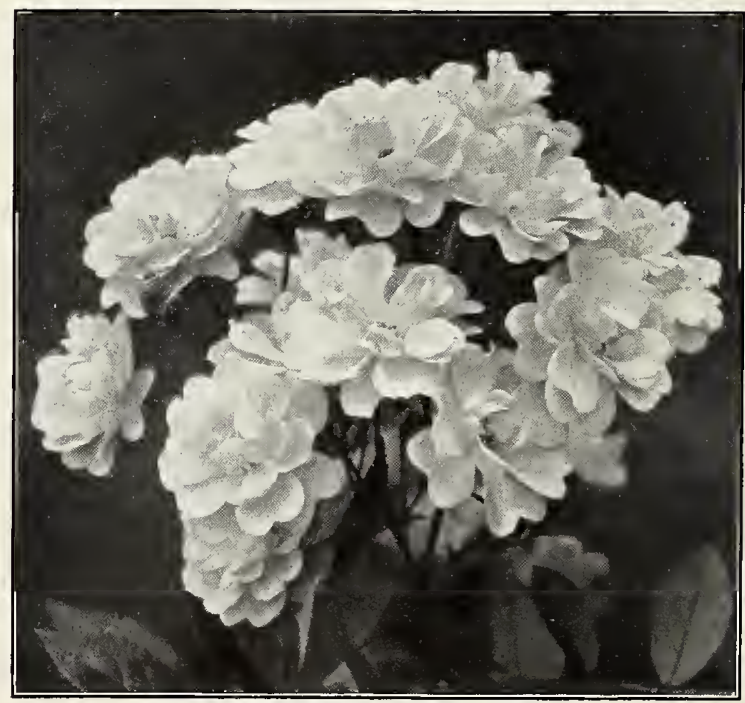

Mrs. William H. Cutbush 
MRS. WILliAM H. CUTBUSH-(P.) Bright, deep pink; blooms in large clusters throughout the growing season; one of the choicest of the "Baby" class............. MOSELLA or Yellow Soupert-(H.P.) Chromeyellow center, shading to creamy-white on thc edges of the petals; a very free bloomer and a fine, hardy bedder.........

MY MARYLAND-(H.T.) Salmon-pink of a soft and pleasing shade, with long stcms and long pointed buds, very full in bloom and exquisitely fragrant................

OLD GOLD-(H.T.) Vivid reddish orange with apricot shading; strong and free....

OPHELIA - (H.T.) Brilliant salmon-flesh shaded with rose on outer cdges of petals, with a heart of glowing peach-pink and orange-yellow blendings; fragrant as Richmond, faultless form in bud and flower; handsome, bright foliage; immune to mildew and black spot.....................

OLIVIA-(H.T.) Deep rose-pink approaching red; nicely pointed buds and dcep, full flowers. A strong and vigorous grower, constantly in bloom. An ideal rose for bedding and cutting...................

ORLEANS - (P.) Brilliant geranium-red, suffused rose and deep cerise. Bushy habit, grows and blooms frcely. The showiest and prettiest of the pink "Baby" class....

PAPA GONTIER-(T.) Dark crimson, passing to glowing crimson; large buds and deep, open, semi-double flowers; a constant bloomer and vigorous grower, valuable for forcing or field planting................

PAULA-(T.) Sulphur yellow with ochre center. Fine form and free.............

PAUL NEYRON-(H.P.) The largest of all rose blooms; hright, shining pink, clear and beautiful; very double and full; finely scented; blooms first season and all sum-

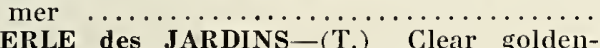
yellow of a rich and beautiful shade; flowers large, globular in form and of great depth; richly perfumed................

PERLE d'OR or Yellow Mlle. Cecile Brunner -(P.) Coppery-gold, changing to fawn; very double and exquisitely perfumed....

PERLE von GODESBERG or Yellow Kaiserin -(H.T.) Canary-yellow of a rich shade, passing toward white. A sport from and otherwise identical with the whitc K. A.

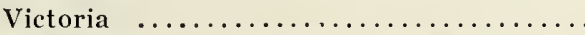

PHILADELPHIA CRIMSON R A M B L E R-

(C.P.) Deep, rich crimson, brighter and more intense than the old Crimson Rambler, with larger, fuller and more lasting flowers in panicles; extremely vigorous and productive, one of the hardiest, and entirely free from mildew.............

PINK RAMBLER or Euphrosyne-(C.P.) A vigorous climber, producing large trusscs of delightfully fragrant flowers of deep pink .................................... PRAIRIE QUEEN-(H.C.) Bright rosy-red large, compr A standard favorite..................... shining, intense and distinctive color; of beautiful, globular form, perfect in stem and handsome, glossy foliage............
Field Pots Pots $y^{\prime} r 2$ y'r X-size

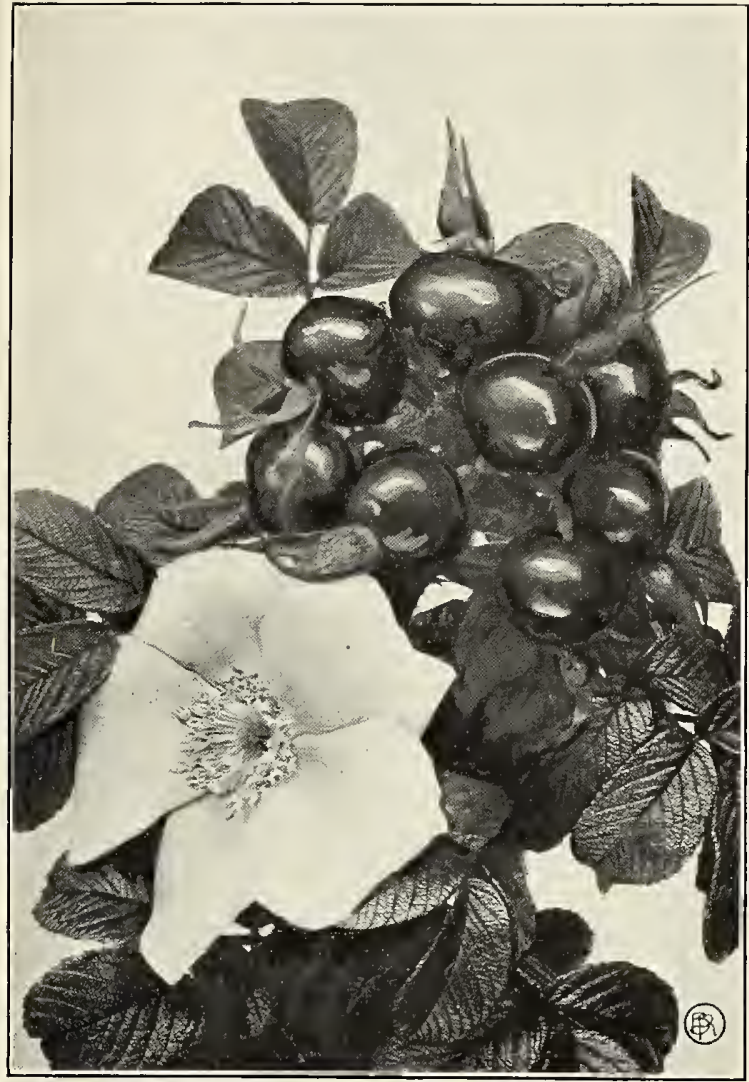

Rosa rugosa alba

PRINCE CAMILLE de ROHAN-(H.P.) UniField Pots Pots versally known as "The Black Rose," owing to its very deep, vcluety crimson color, passing to intense maroon, shaded black: large, handsomc and fragrant blooms....

PRINCE de BULGARIE - (H.T.) Silveryflesh, vcry delicately shaded to golden-salmon center; large, full and cup-formcd...

I'RINCE d'ARENBERG - (H.T.) Brilliant, fiery scarlet, shaded maroon; admirably formed buds, massive petals and perfect

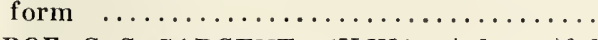

IROF. C. S. SARGENT-(H.V.) A beautiful rose of delicate buff with center of deep golden yellow. Flowers very double and

fragrant $\ldots \ldots \ldots \ldots \ldots \ldots \ldots \ldots \ldots \ldots \ldots$
IPRINCESSE ADELAIDE -
(M.) Bright rosypink; large, douhle and fragrant; buds beautifully mossed ....................

QUEEN OF SPAIN-(H.T.) Delicate flesh with darker tints in center; large, smooth petals of excellent texture, forming perfectly shaped, full flowers of great size, with high

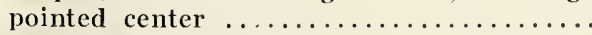

.50 RADIANCE-(H.T.) Brilliant rosy-carmine, shaded with rich opalinc-pink tints in the open flower, which is large, full, of fine form, with cupped petals. See "Roses of

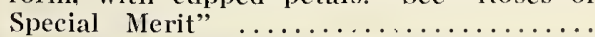

\section{LEXINGTON, M A SSA G H USETTS}


RHEA REID-(H.T.) Flowers rich red, very double and fragranl. A grand bedding rose

RICHMOND-(H.T.) Scarlel-crimson of a most brilliant hue; long poinled buds and beautifully striking flowers on tall, erecl slems; handsome dark foliage; a rapid grower and constant producer............

ROBIN HOOD-(H.T.) Rosy-scarlet color at once sofl, briglit and lasting; bloom full and of beauliful form; a ready grower and

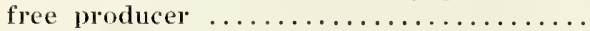

ROSERAIE DE L'HAY - (H.lR.) Flower's bright red and inlensely fragrant; free bloomer. The best of the double red rugosas $\ldots \ldots \ldots \ldots \ldots \ldots \ldots \ldots \ldots \ldots \ldots \ldots \ldots \ldots \ldots$

SAFRANO - (T.) Brighl apricot-ycllow, changing lo orange-fawn, reverse of pelals linted wilh flesh-pink; splendid buds and fine slar-shaped flowers; vigorous, productive

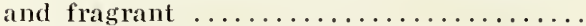

SALET-(M.) Rose-pink, very large, full and beaulifully mossed ................

SHOWER OF GOLD-(H.IV.) Deep goldenyellow and orange flowers borne in splendid trusses forming a mass of bloom.....

SILVER MOON-(H.IV.) Clear silvery-white with a mass of bright yellow stamens; petals of splendid substance and heautifully cupped; exceedingly large and fragranl flowers; growh vigorous and very freeblooming. A desirable new climber......

SNOWDRIFT-(H.W.) Double while climber of vigorous growlh; free blooming; fine

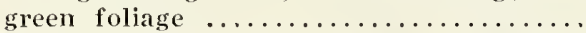

SNOW QUEEN-(See Frau Karl Druschki.)

SOLEIL D'OR (Golden Sun)-(P.) Flowers reddish gold, orange yellow, nasturtiumred and rosy pink. Spicy orange fragrance

SOUTH ORANGE PERFECTION - (H.W.) Sofl blush-pink al the tips, changing to while; perfectly formed, douhle blooms in profusion; a hardy climber or Irailer....

SOUVENIR de PIERRE NOTTING-(T.) A seedling of Marechal Niel and Maman Cochel. Color combining creamy-white fainl orange-yellow and lighl peach, wilh edges of petals bordered in carmine-rose, all blending in beauliful harmony.......

SOUVENIR du PRESIDENT CARNOT-(H.T.) Long, beaulifully pointed buds; flowers delicale flush-while, shaded a trifle deeper al the cenler, very slightly suffused with fawn $\ldots \ldots \ldots \ldots \ldots \ldots \ldots \ldots \ldots \ldots \ldots \ldots$

SUNBURST-(H.T.) An excellent yellow bedder. See "Roses of Special Merit".......

TAUSENDSCHON or Thousand Beauties(C.P.) Varying shades from a delicalely flushed white 10 a deep pink or rosy-carmine, in bright clusters of blossoms almost covering the handsome pale-green foliage. A vigorous, hardy climher with few lhorns

THALIA - (See White Rambler.)

TOM WOOD-(H.T.) Cherry-red, large and double; shell-shaped pelals. A really grand variely $\ldots \ldots \ldots \ldots \ldots \ldots \ldots \ldots \ldots \ldots$

TRIER-(C.P.) Creamy-white, semi-double, free and continuous, blooming in large

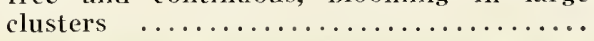

Field Pots Pots

.50
ULRICH BRUNNER-(H.P.) Brilliant cherryred flowers of immense size and bold globular form. Seedling of Paul Neyron, strong and disease-resisting. (See page 10 ).....

UNIVERSAL FAVORITE-(H.W.) Beautiful rosy-pink, resembling "Bridesmaid"; large and double; a rapid climber or trailer of free branching and blooming habit.......

VEILCHENBLAU or Blue Rambler-(C.P.) A sport from Crimson Rambler and as vigorous a climber; produces immense panicles of blooms, opening reddish-lilac, changing to amethyst and steel-hlue. The nearest approach to a hlue Rose..............

VISCOUNTESS FOLKSTONE (H.T.) Creamywhile, deep salmon-pink center; large and full. A grand old rose...............

WELLESLEY-(H.T.) Bright, clear salmonrose, reverse of petals silvery-rose; retains the form of Liberty and the fullness of

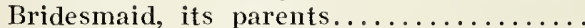

WHITE BABY RAMBLER-(See Catherine Zeimet.)

WHITE CAROLINE TESTOUT-(H.T.) Same as Mad. Caroline Testoul, except lhat the color is pure white...................

WHITE DOROTHY PERKINS-(H.iW. A pure white sport from Dorothy Perkins, with which it is identical in foliage and hahit. A valuahle addition to the hardy climber

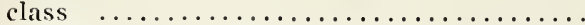

WHITE KILLARNEY-(H.T.) A pure white sport from the pink parent; the newest thing in a forcing Rose, admittedly a strong competitor of The Bride. Our stock is of the true Wahan strain........

WHITE MAMAN COCHET-(T.) Very large and beautifully formed in bud and hloom; pure waxy-white under glass, laking on a faint pink flush out of doors which enhances its beauly. Vigorous and produces

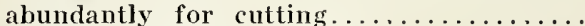

WHITE RAMBLER or Thalia-(C.P.) Grows vigorously. Pure white flowers in clusters

WICHURAIANA or Memorial Rose - (IV.) Pure shining white with hright golden center; single large blossoms borne profusely in July; glossy dark green leaves.........

WILLIAM NOTTING-(H.T.) Bright posycerise with deeper center. Large, full and

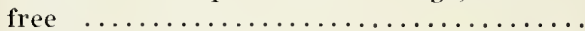

WILLIAM R. SMITH-(T.) Creamy white with shadings of pink, a seedling from Maman Cochet and liaiserin Augusta Victoria. Beautiful in form and colors; glossy foliage, long, stiff stems; vigorous in growth. A superh summer hedder and hardy with light protection............

WILLOWMERE-(H.T.) Long, carinine-coralred hud, opening to large, handsorre, cupped flower of rich shrimp, shaded yellow in the center and toning to carminepink loward edges of petals. A vigorous grower of erect branching habit; long, slout flower stalks, few lhorns, and light green foliage $\ldots \ldots \ldots \ldots \ldots \ldots \ldots \ldots \ldots \ldots$ WINNIE DAVIS-(H.T.) Apricot-pinls, with lighter tints. Buds long and fine form. One of the hest H.T.'s grown.......... YELLOW RAMBLER or Aglaia-(C.P.) hardy climber. Douhle golden-yellow flow-

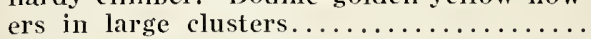

Field Pots Pots y'r 2 y'r X-size

We give no warranty expressed or implied as to deseription, quality, productiveness or any other matter of any Nursery Stock, Seeds, Bulbs or Plants we sen. 


\section{THE \\ BRECK ORGANIZATION \\ Breck's Seed Store and Agricultural Warehouse \\ Established 1822}

"EVERYTHING FOR THE FARM, GARDEN AND LAWN"

51 and 52 North Market St, Boston

\section{Breck-Robinson Nursery Co.}

TREES, PLANTS AND PLANTING LANDSCAPE SERVICE NURSERIES AND SEED TRIAL GROUNDS

Munroe Station, Lexington

Boston Office, 51-52 North Market St.

\section{Breck's Real Estate Agency \\ Incorporated}

FARMS AND COUNTRY ESTATES

Room 45, Ames Building, Boston

Breck's Horticultural and Agricultural

Registry

FREE SERVICE TO EMPLOYER AND EMPLOYEE

51 and 52 North Market St., Boston

Breck's Bureau of Registry

and Information

ALL CLASSES OF MERCANTILE HELP FURNISHED

55 Franklin St., Boston

"AT YOUR SERVICE" 

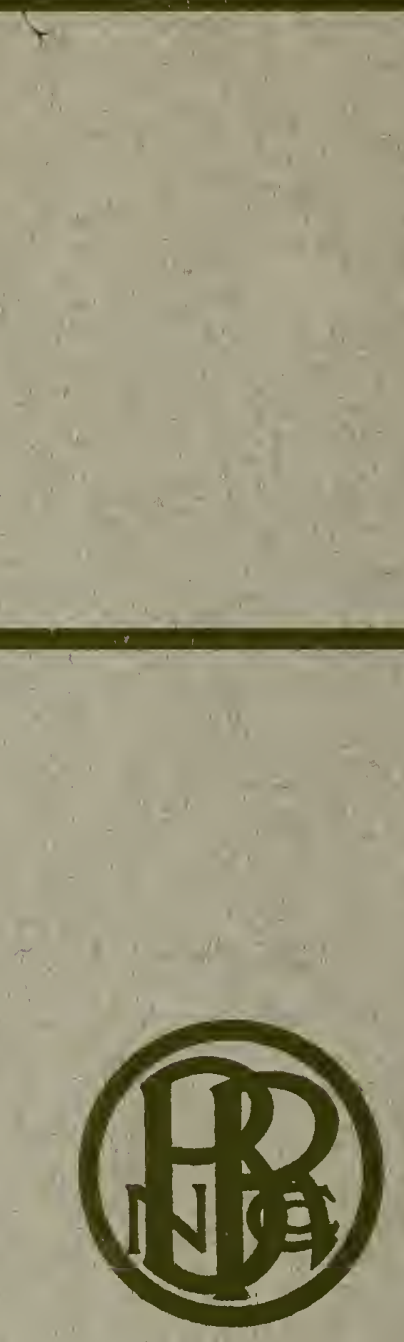